\title{
STRATEGI KOMUNIKASI PEMASARAN 7P PENGELOLA MUSEUM SEJARAH JAKARTA DALAM UPAYA MENINGKATKAN DAYA TARIK WISATAWAN MANCANEGARA
}

\author{
Anissa Aprilia Adhianti ${ }^{1 *}$, Herlinda $^{2}$ \\ ${ }^{1,2}$ Fakultas Ilmu Komunikasi Universitas Gunadarma \\ Jl. Margonda Raya No. 100, Depok 16424, Jawa Barat \\ Email: ${ }^{1}$ anissapriliadhianti@gmail.com; ${ }^{2}$ herlinda.eca@gmail.com \\ *Penulis korespondensi
}

\begin{abstract}
ABSTRAK
Penelitian ini menggunakan pendekatan kualitatif bersifat deskriptif. Objek penelitian ini adalah strategi komunikasi pemasaran pengelola Museum Sejarah Jakarta dalam upaya meningkatkan daya tarik wisatawan mancanegara. Proses pengumpulan data dilakukan melalui observasi, wawancara, studi kepustakaan, dan dokumentasi. Data dianalisis melalui tiga cara yaitu reduksi data, penyajian data dan menarik kesimpulan. Hasil penelitian ini menunjukkan bahwa strategi komunikasi pemasaran yang dilakukan oleh pengelola Museum Sejarah Jakarta diantaranya menggunakan brosur, pamflet, pemasaran langsung secara persuasif, menyelenggarakan event yang unik dan menarik, dan melalui social media seperti instagram dan facebook. Selain itu pengelola Museum Sejarah Jakarta menerapkan bauran komunikasi pemasaran $7 \mathrm{p}$ (product, price, promotion, place, people, process, physical evidence) dari manfaat informasi untuk para wisatawan mancanegara, potongan harga untuk rombongan, kemudahan akses untuk para wisatawan mancanegara yang ingin berkunjung, event yang diselenggarakan bertemakan sejarah maupun edukasi, dan koleksi yang berbeda dengan museum lainnya.
\end{abstract}

Kata kunci: Komunikasi pemasaran 7p; meningkatkan daya tarik; museum sejarah Jakarta; strategi wisatawan mancanegara.

\begin{abstract}
The process of collecting data is done through observation, interviews, literature studies, and documentation. Data were analyzed in three ways, namely data reduction, data presentation and attracting conclusions. The results of this study indicate that marketing communication strategies carried out by the managers of the Jakarta History Museum include using brochures, pamphlets, direct marketing persuasively, organizing unique and interesting events, and through social media such as Instagram and Facebook. In addition, the manager of the Jakarta History Museum applies a marketing mix of $7 p$ (product, price, promotion, place, people, process, physical evidence) from the benefits of information for foreign tourists, discounts for groups, easy access for foreign tourists who want to visit, events that are held with the theme of history and education, and different collections from other museums.
\end{abstract}

Keywords: Marketing communication 7p; increase attractiveness; jakarta history museum; strategy foreign tourists.

\section{PENDAHULUAN}

Kota Jakarta merupakan ibukota Negara yang memiliki perkembangan dan kemajuan yang sangat pesat di berbagai bidang dan sektor seperti pusat perkantoran, perdagangan, pemerintahan, dan bisnis. Melihat pertumbuhan dan perkembangan kota Jakarta yang sangat cepat dan pesat, banyak orang yang datang berbondong-bondong untuk mengadu nasib di Jakarta.

Jakarta memiliki banyak destinasi wisata dan memiliki daya tarik wisata yang tinggi baik untuk wisata lokal maupun internasional. Segala jenis tempat rekreasi, mall, pantai, taman bermain dan tempat bersejarah pun semua ada disini. Khususnya tempat bersejarah di Jakarta, yaitu Museum Sejarah
Jakarta. Salah satunya Kota Tua, Kota Tua adalah kawasan wisata yang paling banyak dikunjungi oleh pengunjung baik lokal maupun internasional, salah satu obyek wisata unggulan di Jakarta adalah salah satunya Museum Sejarah Jakarta. Dahulu masyarakat lebih mengenalnya Museum Fatahillah, tetapi yang dimaksud Museum Fatahillah merupakan bagian depan Taman Fatahillah, sedangkan yang dimaksud Kota Tua yaitu sebuah kota lama dan terdapat banyak museum diantaranya: Museum Sejarah Jakarta, Museum Wayang, dan Museum Bahari yang dikelola oleh Dinas Pariwisata dan Kebudayaan DKI Jakarta atau Pemerintah Provinsi DKI Jakarta sedangkan yang dikelola oleh pihak swasta adalah Museum Bank Indonesia, Museum Bank Mandiri, Museum 3 Dimensi, Museum BNI masih dalam pengawasan Tata Usaha Kota Tua. 
Kota Tua memiliki unit yaitu Unit Pengelola Kota Tua (UPK) yaitu merupakan badan yang mengawasi atau menangani lingkungan atau lingkup area Kota Tua, sedangkan Museum Sejarah Jakarta memiliki badan atau unit sendiri yang bernama UP MKJ yaitu Unit Pengelola Museum Kesejarahan Jakarta yang membawahi, diantaranya: Museum Sejarah Jakarta, Museum Prasasti, Museum Joang 45, dan Museum MH. Thamrin. Dalam tiap berbagai wisata memiliki strategi komunikasi untuk daya tarik para wisatawan lokal maupun internasional, seperti halnya Museum Sejarah Jakarta yang memiliki strategi komunikasi pemasaran itu sendiri karena sebagai tempat wisata unggulan di Jakarta. Komunikasi pemasaran merupakan kegiatan komunikasi dalam pemasaran dengan menggunakan teknik dan cara komunikasi yang bertujuan untuk memberikan informasi dan pemahaman kepada orang lain dengan harapan supaya tujuan lembaga dapat tercapai. Komunikasi pemasaran berfungsi untuk memperoleh segmentasi yang lebih luas untuk memperkuat loyalitas pelanggan terhadap produk yang dimiliki lembaga.

Kegiatan komunikasi pemasaran membutuhkan waktu serta strategi yang baik supaya komunikasi yang dilakukan dapat berlangsung efektif, karena strategi komunikasi pemasaran (marketing communication) yang tepat dapat menghindarkan dari kerugian yang disebabkan oleh kegiatan promosi yang tidak efektif dan efisien, kegiatan promosi yang efektif dan efisien termasuk sebagai bagian dari konsep bauran komunikasi pemasaran. Pada konsep bauran komunikasi pemasaran meliputi 7P yaitu (Product, Price, Promotion, Place, People, Process, dan Physical Evidence). Strategi komunikasi adalah kegiatan komunikasi yang sifatnya informasional maupun persuasif untuk membangun pemahaman dan dukungan terhadap suatu ide, gagasan atau kasus, produk maupun jasa yang terencana yang dilakukan oleh suatu organisasi baik yang berorientasi laba maupun nirlaba, memiliki tujuan, rencana dan berbagai alternatif berdasarkan riset dan memiliki evaluasi (Smith, 2005:3). Dapat dikatakan bahwa proses yang membentuk hubungan antara produsen dengan individu, atau kelompok dalam menyampaikan macam-macam produk: barang dan jasa, dilakukan untuk memenuhi keinginan dan kebutuhan (needs and want), guna mencapai tingkat kepuasan yang lebih tinggi melalui penciptaan produk yang berkualitas. Pariwisata bukan saja sebagai sumber devisa, tetapi juga merupakan faktor dalam menentukan lokasi industri dalam perkembangan daerah-daerah yang miskin sumber-sumber alam sehingga perkembangan pariwisata adalah salah satu cara untuk memajukan ekonomi di daerah-daerah yang kurang berkembang tersebut sebagai akibat kurangnya sumber-sumber alam dan strategi komunikasi pemasaran sangat penting untuk mencapai tujuan guna yang telah ditetapkan. Dari berbagai uraian di atas, maka perumusan masalah peneliti adalah: Bagaimana penerapan strategi komunikasi pemasaran 7P pengelola Museum Sejarah Jakarta dalam upaya meningkatkan daya tarik wisatawan mancanegara?

\section{HAKIKAT KOMUNIKASI}

\subsection{Komunikasi Sebagai Ilmu}

Di fakultas, jurusan atau program studi ilmu komunikasi di negara kita belum banyak perkembangannya, setidaknya sebagai bidang ilmu (mata kuliah) dan sebagai bidang penelitian. Komunikasi kesehatan khususnya sangat potensial untuk menjadi bukan hanya sebagai mata kuliah atau konsentrasi, namun juga sebagai program studi, mengingat eratnya hubungan komunikasi (dokter, perawat, manajer rumah sakit) dengan bidang medis, juga mengingat penduduk kita berjumlah 240 juta, yang sebagiannya sering sakit- sakitan dan menggunakan berbagai macam cara untuk mengobati penyakit mereka.

\subsection{Komunikasi sebagai Penelitian}

Paradigma ilmu komunikasi yang sudah kita kenal sejauh in paradigma ilmu-ilmu sosial lainnya, terdiri dari tiga paradigma, yakni paradigma konstruksionis (Max Weber), paradigma kritis (Karl Marx), dan paradigma klasik atau objektivis (Emile sebagaimana Durkheim). Maka paradigma yang cocok untuk meneliti fenomena komunikasi masyarakat Asia adalah paradigma fenomenologis (konstruksionis) yang proses penelitiannya bersifat induktif alih-alih deduktif. Selama beberapa dekade kita didominasi oleh paradigma positivistik (deduktif) yang sebenarnya lebih cocok untuk masyarakat Eropa dan Amerika (budaya eurosentrik yang mengasumsikan bahwa yang nyata itu real, manusia sebagai menjadi satuansatuan yang diatur oleh hukum bersifat tetap).

\subsection{Komunikasi sebagai Keterampilan}

Kemampuan berkomunikasi akan semakin prospektif untuk memajukan karier dalam bidang apapun. Karena komunikasi bersifat omnipresent (hadir di mana-mana), kita dapat memasuki lembaga atau perusahaan apa pun karena tiap organisasi itu pasti membutuhkan orang yang cakap berkomunikasi, baik secara lisan ataupun tertulis. 


\subsubsection{Strategi Komunikasi}

Kata strategi dari bahasa Yunani klasik yaitu "stratos" yang artinya tentara dan kata "agein" yang berarti memimpin. Dengan demikian, strategi dimaksudkan adalah memimpin tentara. Lalu muncul kata strategos yang artinya pemimpin tentara pada tingkat atas. Karl von Clausewitz (1780-1831) seorang pensiunan jenderal Rusia dalam bukunya On War merumuskan strategi ialah "suatu seni menggunakan sarana pertempuran untuk mencapai tujuan perang". Strategi menghasilkan gagasan dan konsepsi yang dikembangkan oleh para praktisi. Karena itu para pakar strategi tidak saja lahir dari alangan yang memiliki latar belakang militer, tapi juga dari profesi lain, misalnya pakar strategi Henry Kissinger berlatar belakang sejarah, Thomas Schelling berlatar belakang ekonomi, dan Albert Wohlsetter berlatar belakang matematika.

Karena itu, maka strategi komunikasi selalu dihubungkan dengan:

1. Siapa saya berbicara

2. Maksud apa saya bicara

3. Pesan apa yang harus disampaikan kepada seseorang

4. Cara bagaimana saya menyampaikan pesan kepada seseorang

\subsubsection{Strategi Komunikasi Pemasaran}

Komunikasi pemasaran merupakan perpaduan tiga disiplin ilmu, pemasaran, komunikasi dan manajemen strategi, menghasilkan "Strategi komunikasi pemasaran" atau sering disebut juga "komunikasi pemasaran korporat". Berbagai macam faktor eksternal dan internal berinteraksi dalam suatu mekanisme yang menggunakan untuk mempengaruhi kemampuan sebuah perusahaan dalam memasarkan produknya. Perusahaan juga dituntut memiliki kemampuan berkomunikasi dengan para pelanggan yang potensial, pengecer, pemasok, masyarakat dan semua pihak yang memiliki kepentingan dengan perusahaan.

Komunikasi pemasaran merupakan multidisiplin yang menggunakan teori dan konsep ilmu komunikasi dengan ilmu pemasaran. Marketing communication adalah kegiatan pemasaran dengan menggunakan teknik-teknik komunikasi yang bertujuan untuk memberikan informasi pada orang banyak agar tujuan perusahaan tercapai yaitu terjadinya peningkatan pendapatan atas penggunaan jasa atau pembelian produk yang ditawarkan. Selain itu komunikasi pemasaran juga diartikan sebagai proses menjalin dan memper- kuat hubungan yang saling menguntungan dengan karyawan, pelanggan, serta semua pihak dengan mengembangkan dan mengkoordinasikan program komunikasi strategi agar memungkinkan mereka melakukan kontrak konstruktif dengan perusahaan merek produk melalui berbagai media.

\subsubsection{Konsep Promosi}

Pada dasarnya maksud kata promosi adalah untuk memberitahukan, membujuk atau mengingatkan lebih khusus lagi. Promosi merupakan suatu proses menyampaikan informasi kepada target pasar, tentang hal-hal yang menyangkut produk, harga, tempat produk dijual dengan melakukan persuasif agar target mau melakukan pembelian.

Promosi merupakan salah satu variabel dalam bauran pemasaran, yang sangat penting dilakukan oleh perusahaan dalam memasarkan produk jasa. Dapat disimpulkan bahwa promosi dalam pariwisata adalah arus informasi satu arah dibuat mengarahkan calon wisatawan atau lembaga usaha pariwisata kepada tindakan yang mampu menciptakan pertukaran (jual beli) dalam pemasaran produk pariwisata. Promosi dalam pemasaran produk pariwisata berperan sebagai pendukung transaksi dengan menginformasikan, membujuk, mengingatkan dan membedakan produk pariwisata yang dipromosikan dengan produk pariwisata perusahaan lain.

\subsubsection{Pariwisata}

Secara etimologi pariwisata berasal dari bahasa sansekerta yang terdiri dari dua suku kata Pra yang berarti banyak, berkali-kali, berputar-putar, lengkap. Dan kata wisata yang berarti perjalanan, bepergian yang bersinonim dengan kata travel dalam bahasa Inggris, maka dapat diartikan bahwa pariwisata adalah perjalanan yang dilakukan berkali-kali atau berputar-putar dari satu tempat ke tempat lain.

Menurut James J. Spillance Pariwisata adalah perjalanan dari satu tempat ke tempat lain yang bersifat sementara dilakukan perorangan atau kelompok sebagai usaha mencari keseimbangan, keserasian dalam dimensi sosial budaya. Pariwisata adalah suatu perjalanan yang dilakukan untuk sementara waktu yang diselenggarakan dan suatu tempat ke tempat lain dengan maksud tujuan bukan untuk berusaha atau mencari nafkah di tempat yang dikunjungi, tetapi semata-mata menikmati perjalanan tersebut untuk memenuhi kebutuhan atau keinginan yang bermacam-macam. 
Menurut undang-undang No. 10 Tahun 2009 tentang Kepariwisataan disebutkan wisatawan adalah orang yang melakukan wisata. Sedangkan Sihte pengertian wisatawan dapat dibagi menjadi dua, yaitu:

1. Wisatawan nusantara adalah wisatawan dalam negeri atau wisatawan domestik.

2. Wisatawan mancanegara adalah warga Negara suatu Negara yang mengadakan perjalanan wisata keluar lingkungan dari negaranya (memasuki negara lain).

\subsubsection{Komunikasi Pemasaran Terpadu}

Seperti yang dikemukakan Larry Percy (2008) dalam buku Strategis Integrated Marketing Communications, bahwa komunikasi pemasaran terpadu mulai menjadi pokok bahasan dalam industri periklanan atau komunikasi pemasaran pada akhir 1980-an. Diawali oleh the American Association of Advertising Agency (Four A's) dengan pembentukan gugus tugas (task face) yang membahas tentang integrasi, dan menelorkan definisi tentang komunikasi pemasaran terpadu, dan menyatakan bahwa komunikasi pemasaran terpadu adalah suatu konsep perencanaan komunikasi pemasaran yang memperkenalkan nilai tambah dari suatu rencana komprehensif, mengevaluasi peranan strategi dari berbagai disiplin komunikasi (seperti advertising, direct response, sales promotion, dan public relations), dan mengkombinasikan berbagai disiplin tersebut untuk mengupayakan kejelasan, konsistensi, dan dampak komunikasi yang maksimum.

Adapun Don Schultz dan kawan-kawan (1993), dalam buku Integrated Marketing Communication, mengemukakan bahwa komunikasi pemasaran terpadu merupakan cara baru yang melihat pada totalitas yang nyata, biasanya kita hanya melihat program komunikasi pemasaran sebagai bagian perbagian, seperti advertising, public relations, sales promotion, purchasing, ataupun aktivitas pekerja pada level komunikasi saja, tanpa atau sedikit dikaitkan dengan aktivitas pemasaran, bahkan bisnis, dan aktivitas perusahaan lainnya.

Buku karangan Schultz ini mungkin merupakan buku pertama yang membahas secara konkret tentang komunikasi pemasaran terpadu, yang dimaknakan sebagai penyusunan pola komunikasi berbalik, diawali dari pemahaman sudut pandang konsumen kemudian dikembangkan ke dalam suatu strategi alur informasi dalam bisnis dan pemasaran. (dalam Gitosudarmo, 2017: 60-61)

\subsubsection{Bauran Promosi}

Kegiatan promosi tidak boleh berhenti hanya pada memperkenalkan produk kepada konsumen saja, akan tetapi harus dilanjutkan dengan upaya untuk mempengaruhinya agar konsumen tersebut menjadi senang dan kemudian membeli produknya. Adapun alat-alat yang dapat dipergunakan untuk mempromosikan suatu produk, dapat dipilih beberapa cara yaitu:

1. Iklan atau advertensi

Advertensi merupakan alat utama bagi pengusaha untuk mempengaruhi konsumennya. Advertensi ini dapat dilakukan oleh pengusaha lewat surat kabar, radio, majalah, bioskop, televisi maupun dalam bentuk poster-poster yang dipasang di pinggir jalan atau tempat-tempat yang strategis. Dengan membaca atau melihat advertensi itu diharapkan para konsumen atau calon konsumen akan terpengaruhi lalu tertarik untuk membeli produk yang di advertansikan tersebut.

2. Promosi penjualan (Sales Promotion)

Promosi penjualan adalah merupakan kegiatan perusahaan untuk menjajakan produk yang dipasarkannya sedemikian rupa sehingga konsumen akan mudah untuk melihatnya bahkan dengan cara penempatan dan pengaturan tertentu maka produk tersebut akan menarik perhatian konsumen. Dengan cara memasang produk tersebut di etalase toko, bentuk lain dari sales promotion ini adalah dengan memberikan kepada calon konsumen, dan bentuk lain adalah dengan cara mengadakan demonstrasi.

3. Publikasi (Publication)

Publisitas merupakan cara yang biasa digunakan juga oleh pengusaha untuk membentuk pengaruh secara tidak langsung kepada konsumen agar mereka menjadi tahu dan menyenangi produk yang dipasarkannya. Cara ini dilakukan dengan cara membuat berita tentang produk atau perusahaan yang menghasilkan produk tersebut di mass media. Yang membedakan publisitas ini dengan iklan adalah bahwa publisitas ini bersifat berita yang tidak komersial sedangkan iklan itu harus membayar untuk keperluan tersebut.

4. Personal selling

Personal selling merupakan kegiatan perusahaan untuk melakukan kontak langsung dengan para calon konsumennya. Dengan kontak langsung ini diharapkan kan terjadi hubungan atau interaksi yang positif antara pengusaha dengan calon konsumennya itu. Kontak langsung itu akan dapat mempengaruhi secara lebih intensif para konsumennya karena dalam hal ini pengusaha dapat 
mengetahui keinginan dan selera konsumennya serta gaya hidupnya dan dengan demikian maka pengusaha dapat menyesuaikan cara pendekatan atau komunikasinya dengan konsumen itu secara lebih tepat yang sesuai dengan konsumen yang bersangkutan.

\subsubsection{Bauran Komunikasi Pemasaran (Marketing Mix)}

Marketing Mix atau bauran pemasaran adalah kombinasi dari ketujuh variabel yaitu produk, struktur harga, kegiatan promosi, sistem distribusi, karyawan, proses, dan lingkungan fisik (Kotler, 2002). Ketujuh unsur bauran pemasaran tersebut saling berhubungan dan berpengaruh satu sama lain sehingga harus diupayakan untuk menghasilkan suatu kebijakan pemasaran yang mengarah kepada layanan efektif dan kepuasan konsumen. Ketujuh unsur bauran pemasaran tersebut dapat dikemukakan sebagai berikut:

1. Produk (product)

Produk merupakan elemen penting dalam sebuah program pemasaran. Strategi produk dapat mempengaruhi strategi pemasaran lainnya. Pembelian sebuah produk bukan hanya sekedar untuk memiliki produk tersebut tetapi juga untuk memenuhi kebutuhan dan keinginan konsumen. Dalam bisnis ada lima dimensi yang penting mengenai kesuksesan suatu produk yaitu: layanan, keandalan, jaminan, tanggap dan identifikasi (Kotler, 2002).

2. Harga (price)

Harga menurut Kotler dan Amstrong (2001) adalah sejumlah uang yang ditukarkan untuk sebuah produk atau jasa. Lebih jauh lagi, harga adalah jumlah dari seluruh nilai yang konsumen tukarkan untuk jumlah manfaat dengan memiliki atau menggunakan. Harga dapat menunjukkan kualitas merek dari suatu produk, dimana konsumen mempunyai anggapan bahwa harga yang mahal biasanya mempunyai kualitas yang baik.

3. Promosi (promotion)

Promosi merupakan teknik komunikasi yang secara penggunaannya atau penyampaiannya dengan menggunakan media seperti: pers, televisi, radio, papan nama, poster, dan lain-lain yang tujuannya untuk menarik minat konsumen terhadap hasil produksi suatu perusahaan. Promosi sebagai media untuk menjembatani kepentingan produsen dengan konsumen harus benar-benar dipahami oleh seorang manajer.

4. Saluran Distribusi (Place)

Kotler (2000) menyatakan bahwa "saluran distribusi terdiri dari seperangkat lembaga yang melakukan segala kegiatan, fungsi yang digunakan untuk menyalurkan produk dan status pemiliknya dari produsen ke konsumen". Dari definisi diatas dapat diartikan bahwa saluran distribusi suatu barang adalah keseluruhan kegiatan atau fungsi untuk memindahkan produk disertai dengan hak pemiliknya dari produsen ke konsumen.

5. Partisipan (people)

Yang dimaksud partisipan adalah karyawan penyedia jasa layanan maupun penjualan, atau orang-orang yang terlibat secara langsung maupun tidak langsung dalam proses layanan itu sendiri, diantaranya adalah para manager, perception, mekanik, dan marketing. Kotler dan Amstrong (2001).

6. Proses (process)

Proses adalah kegiatan yang menunjukkan bagaimana pelayanan diberikan kepada konsumen selama melakukan pembelian barang. Pengelola klinik melalui frontliner sering menawarkan berbagai macam bentuk pelayanan untuk tujuan menarik konsumen

7. Lingkungan Fisik (Physical Evidence)

Lingkungan fisik adalah keadaan atau kondisi yang di dalamnya juga termasuk suasana tempat beroperasinya jasa pelayanan. Karakteristik lingkungan fisik merupakan segi yang paling nampak dalam kaitannya dengan situasi, dekorasi, ruangan, suara, aroma, cahaya, cuaca, peletakkan dan layout yang nampak atau lingkungan yang penting sebagai objek stimuli. (Ibnularoby. 2013: 15-26)

\section{METODE PENELITIAN}

Metode penelitian ini adalah menggunakan penelitian kualitatif deskriptif. Dalam penelitian kualitatif, populasi diartikan sebagai wilayah generalisasi yang terdiri atas: objek/subjek yang mempunyai kualitas dan karakteristik tertentu yang ditetapkan oleh peneliti untuk dipelajari dan kemudian ditarik kesimpulannya. Sedangkan sampel adalah sebagian dari populasi itu (Sugiyono, 2008: 297). Paradigma yang digunakan oleh peneliti adalah paradigma konstruktivisme, yaitu pendekatan yang lebih terfokus pada sebuah bidang khusus.

\subsection{Teknik Pengumpulan Data}

Metode pengumpulan data dalam penelitian ini adalah:

1. Data Primer

Data primer adalah data yang diperoleh dan berkaitan langsung dengan permasalahan yang dihadapi dalam penelitian ini.

Pengumpulan data yang digunakan adalah:

a. Wawancara yaitu dengan mengajukan pertanyaan-pertanyaan secara langsung dan terbuka kepada informan atau pihak yang berhubungan dan memiliki relevansi terhadap masalah yang berhubungan dengan penelitian. 
b. Observasi yaitu dengan mengamati secara langsung dengan mencatat gejala-gejala yang ditemukan di lapangan serta menjaring data yang tidak terjangkau

\section{Data Sekunder}

Data sekunder adalah data yang tidak diperoleh langsung dari objek penelitian.

Pengumpulan data yang dilakukan adalah:

a. Penelitian Kepustakaan yaitu dengan cara mengumpulkan data melalui buku-buku ilmiah, tulisan, karangan ilmiah yang berkaitan dengan penelitian.

b. Dokumentasi yaitu teknik pengumpulan data dengan menggunakan catatan- catatan atau foto-foto yang ada di lokasi penelitian serta sumber-sumber lain yang relevan dengan objek penelitian.

\subsection{Instrumen Penelitian}

Menurut Poerwandari (1998), peneliti sangat berperan dalam seluruh proses penelitian, mulai dari memilih topik, mendeteksi topik tersebut, mengumpulkan data, hingga analisis, menginterpretasikan dan menyimpulkan hasil penelitian. Dalam mengumpulkan data-data, peneliti membutuhkan instrumen penelitian. Dalam penelitian ini menggunakan 3 instrumen, yaitu:

\section{Pedoman wawancara}

Pedoman wawancara digunakan supaya wawancara yang dilakukan tidak menyimpang dari tujuan penelitian. Pedoman ini disusun tidak hanya berdasarkan tujuan penelitian, tetapi juga berdasarkan teori yang berkaitan dengan masalah yang diteliti.

2. Pedoman observasi

Pedoman observasi digunakan agar peneliti dapat melakukan pengamatan sesuai dengan tujuan penelitian. Pedoman observasi disusun berdasarkan hasil observasi terhadap perilaku subjek selama wawancara dan observasi terhadap lingkungan atau setting wawancara, serta pengaruhnya terhadap perilaku subjek dan informasi yang muncul pada saat berlangsungnya wawancara.

3. Pedoman dokumentasi

Pedoman dokumentasi digunakan untuk memperkuat data hasil wawancara dan observasi sehingga data yang dihasilkan akan lebih terpercaya dan memiliki kredibilitas tinggi. (Dzilqarnain, 2015: 41).

\section{HASIL DAN PEMBAHASAN}

\subsection{Komunikasi Pemasaran}

Diawali oleh the American Association of Advertising Agency (Four A's) dengan pembentukan gugus tugas (task face) yang membahas tentang integrasi, dan menelorkan definisi tentang komunikasi pemasaran terpadu, dan menyatakan bahwa komunikasi pemasaran terpadu adalah suatu konsep perencanaan komunikasi pemasaran yang memperkenalkan nilai tambah dari suatu rencana komprehensif, mengevaluasi peranan strategi dari berbagai disiplin komunikasi (seperti advertising, direct response, sales promotion, dan public relations), dan mengkombinasikan berbagai disiplin tersebut untuk mengupayakan kejelasan, konsistensi, dan dampak komunikasi yang maksimum.

Tiap perusahaan atau objek wisata sekalipun memiliki komunikasi pemasaran yang berbeda-beda. Dari hasil data yang diperoleh melalui wawancara peneliti dengan para informan, menurut Bapak Sandy selaku Humas Museum Sejarah Jakarta komunikasi pemasaran yang dilakukan oleh Museum Sejarah Jakarta adalah dengan cara studi banding antara museum satu ke museum lainnya sebagai daya tarik wisatawan mancanegara. Menurut Bapak Galih sebagai Kepala Satuan Pelaksana Event bahwa komunikasi pemasaran yang dilakukan menggunakan komunikasi pemasaran langsung / face to face, dan promosi melalui social media, seperti: instagram dan facebook.

\subsection{Strategi Komunikasi Pemasaran}

Strategi komunikasi pemasaran yang dilakukan di Museum Sejarah Jakarta menurut Bapak Sandy mengatakan bahwa melalui face to face atau pemasaran langsung secara persuasif yang dilakukan tour guide dan tour leader agar pesan yang disampaikan lebih efektif dan juga fasilitas-fasilitas yang disediakan terutama tempat yang menarik untuk berswafoto, para pengunjung bisa mendapatkan edukasi dan juga mendapatkan foto-foto yang unik dan menarik. Menurut Bapak Galih strategi komunikasi pemasaran yang dilakukan adalah menggunakan brosur, pamflet dan social media yang berisikan kegiatan atau event yang akan diselenggarakan maupun yang telah diselenggarakan, terutama strategi komunikasi pemasaran yang dilakukan adalah mengadakan eventevent yang unik dan menarik seperti mengadakan jelajah malam, atraksi teatrikal, seminar, dll sebagai daya tarik wisatawan mancanegara.

Selain itu penyelenggaraan event bekerjasama dengan pihak-pihak terkait seperti: karyawan dan karyawati yang bekerja di Museum Sejarah Jakarta, Dinas Pariwisata, Bank DKI, dan transportasi TransJakarta. Konten event yang akan diposting di social media sehari sebelum penyelenggaraan event sudah diposting tujuannya supaya wisatawan mancanegara 
maupun wisatawan nusantara bisa mengetahui secara up-to-date untuk berpartisipasi atau mengikuti dalam kegiatan tersebut.

\subsection{Bauran Promosi}

Adapun alat-alat yang dapat dipergunakan untuk mempromosikan suatu produk, dapat dipilih beberapa cara yaitu:

a. Iklan atau advertensi

Dari hasil wawancara peneliti dengan informan Bapak Galih iklan atau advertising yang dilakukan menggunakan seperti brosur yang berisikan mengenai profil Museum Sejarah Jakarta dan kegiatan atau event yang akan diselenggarakan diberikan kepada para wisatawan yang berkunjung, tetapi menurut Bapak Sandy dikarenakan penggunaan brosur kurang efektif promosi yang dilakukan melalui social media seperti: instagram dan facebook, karena wisatawan yang saat ini lebih aktif menggunakan social media.

b. Promosi penjualan (Sales Promotion)

Informan Bapak Sandy mengatakan bahwa promosi penjualan di Museum Sejarah Jakarta adalah menaruh pamflet di pintu masuk agar para wisatawan yang berkunjung langsung melihat pamflet tersebut, memberikan informasi mengenai event-event yang unik dan menarik supaya para wisatawan merasakan penasaran dan memberikan potongan harga kepada para pengunjung rombongan.

c. Publikasi (Publication)

Dari hasil wawancara peneliti dengan informan Bapak Galih mengatakan bahwa publikasi di Museum Sejarah Jakarta dengan cara melakukan himbauan dari tour guide ataupun tour leader secara persuasif agar para wisatawan mancanegara ataupun wisatawan nusantara supaya ingin terus berkunjung.

d. Personal selling

Menurut informan Bapak Sandy personal selling yang dilakukan adalah dengan cara pemasaran langsung atau face to face karena pesan yang disampaikan lebih efektif. Selain pemasaran langsung Museum Sejarah Jakarta sebelum mengadakan event biasanya terlebih dahulu mengadakan seminar yang diikuti oleh umum.

\subsection{Bauran Komunikasi Pemasaran (Marketing Mix)}

Ketujuh unsur bauran pemasaran tersebut dapat dikemukakan sebagai berikut: a. Produk (product)

Strategi produk dapat mempengaruhi strategi pemasaran lainnya. Menurut Bapak Sandy dari informasi yang disampaikan sangat bermanfaat bagi para pengunjung wisatawan mancanegara dan wisatawan nusantara dari segi edukasi sudah memenuhi kebutuhan dan keinginan. Lalu dari fasilitas yang disediakan oleh pengelola Museum Sejarah Jakarta dapat memuaskan para wisatawan.

b. Harga (price)

Harga yang merupakan satu-satunya unsur bauran pemasaran yang seringkali dijadikan sebagai bahan pertimbangan bagi konsumen dalam melakukan pembelian tidak bisa dikesampingkan oleh perusahaan. Dari hasil peneliti wawancara dengan informan Bapak Sandy mengatakan bahwa harga tiket yang relatif murah sangat disukai dan disenangi oleh para pengunjung, karena dengan harga tiket yang murah pengunjung mendapatkan pengetahuan atau edukasi sekaligus mendapatkan foto yang bagus dan menarik.

c. Promosi (promotion)

Promosi merupakan teknik komunikasi yang secara penggunaannya atau penyampaiannya dengan menggunakan media. Menurut Bapak Sandy promosi yang dilakukan oleh Museum Sejarah Jakarta adalah menyampaikan promosi melalui social media seperti facebook dan instagram, karena dari social media dapat memberikan informasi yang up-to-date mengenai Museum Sejarah Jakarta dan memberitahu masyarakat mengenai event apa saja yang akan di selenggarakan. Lalu melalui social media juga melakukan pesan yang persuasif dengan cara memberikan himbauan atau ajakan kepada masyarakat untuk berkunjung ke sejarah Jakarta.

d. Saluran Distribusi (place)

Saluran distribusi memperlihatkan berbagai kegiatan yang dilakukan perusahaan untuk menjadikan produk atau jasa yang diperoleh sesuai dengan keinginan konsumen. Dari hasil wawancara peneliti dengan informan Bapak Sandy mengatakan letak Museum Sejarah Jakarta memiliki kemudahan akses dengan saat ini banyaknya transportasi seperti TransJakarta dan Kereta Api sangat mudah dijangkau sesuai dengan keinginan para masyarakat dan destinasi yang paling mudah untuk dijangkau.

e. Partisipan (people)

Yang dimaksud partisipan adalah karyawan penyedia jasa layanan maupun penjualan, atau orang-orang yang terlibat secara langsung maupun tidak langsung dalam proses layanan itu sendiri. 
Menurut informan Bapak Sandy mengatakan Sumber Daya Manusia di Museum Sejarah Jakarta mengenai pengetahuan komunikasi menerapkan strategi komunikasi yang baik untuk tata cara penjualan, penempatan dan promosi. Lalu untuk para tour guide yang bekerja di Museum Sejarah Jakarta sebelum terjun ke lapangan harus mengikuti seperti sertifikasi tour guide yang diadakan oleh Dinas Pariwisata DKI Jakarta.

f. Proses (process)

Proses adalah kegiatan yang menunjukkan bagaimana pelayanan diberikan kepada konsumen selama melakukan pembelian barang. Proses penyampaian jasa pengelola Museum Sejarah Jakarta kepada wisatawan mancanegara menurut informan Bapak Sandy mengatakan bahwa dengan menggunakan service excellent karena dari segi bahasa yang berbeda yaitu menggunakan bahasa asing.

g. Lingkungan Fisik (physical evidence)

Karakteristik lingkungan fisik merupakan segi yang paling nampak dalam kaitannya dengan situasi, dekorasi, ruangan, suara, aroma, cahaya, cuaca, peletakkan dan layout yang nampak atau lingkungan yang penting sebagai objek stimuli. Karakteristik yang dimiliki oleh Museum Sejarah Jakarta menurut informan Bapak Sandy mengatakan bahwa koleksi-koleksi yang dimiliki dan dipamerkan berbeda atau bahkan yang tidak dimiliki dengan museum lainnya dan juga interior yang klasik seperti bangunan jaman Jepang dan Belanda.

Terdapat satu koleksi yang menjadikan ciri khas Museum Sejarah Jakarta yaitu meriam si jagur dan salah satu koleksi tersebut berhasil menarik rasa penasaran wisatawan mancanegara karena memiliki mitos tersendiri. Museum Sejarah Jakarta juga memiliki tim koleksi yang bertugas sebagai menginvestasi dan perawatan koleksi supaya koleksi-koleksi tetap bagus dan terjaga. Dalam menciptakan suasana supaya para wisatawan mancanegara ingin terus berkunjung informan Bapak Sandy mengatakan bahwa dengan cara memberikan excellent service. Selanjutnya menurut informan Bapak Galih untuk menciptakan suasana supaya para wisatawan mancanegara ingin selalu berkunjung ke Museum Sejarah Jakarta dengan cara menyelenggarakan event yang unik dan menarik, selain itu memfollow-up dari event yang tahun sebelumnya dan event apa saja yang banyak disukai oleh para wisatawan mancanegara. Jika dari event tersebut para wisatawannya banyak yang meminati dari Ketua Pelaksana Event akan menyelenggarakan event tersebut kembali. Event-event yang paling banyak disukai seperti atraksi teatrikal, atraksi teatrikal Pangeran Diponegoro, dan Jelajah Malam. Dari event-event yang unik dan menarik diselenggarakan di Museum Sejarah Jakarta sebagai salah satu daya tarik para wisatawan mancanegara.

\section{KESIMPULAN DAN SARAN}

Berdasarkan hasil penelitian dengan judul "Strategi Komunikasi Pemasaran 7P Pengelola Museum Sejarah Jakarta dalam Upaya Meningkatkan Daya Tarik Wisatawan Mancanegara" peneliti dapat menyimpulkan bahwa bauran promosi yang dilakukan oleh pengelola Museum Sejarah Jakarta antara lain melalui iklan atau advertensi berupa brosur dan social media, promosi penjualan berupa pamflet, publisitas berupa melakukan persuasif oleh tour guide atau tour leader, dan personal selling berupa pemasaran langsung dan menyelenggarakan seminar. Hal tersebut dilakukan sebagai usaha daya tarik para wisatawan mancanegara. Bauran komunikasi pemasaran (marketing mix) antara lain produk berupa memberikan informasi yang mengedukasi, harga berupa harga tiket yang relatif murah, promosi berupa social media dan menyelenggarakan event, saluran distribusi berupa kemudahan akses transportasi, partisipan berupa tour guide yang harus mengikuti kursus, proses berupa dengan memberikan service excellent kepada wisatawan mancanegara, dan lingkungan fisik berupa koleksi yang memiliki ciri khas dan berbeda dengan museum lain, dan event yang diselenggarakan oleh Museum Sejarah Jakarta. Selain itu, strategi komunikasi pemasaran yang dilakukan pengelola Museum Sejarah Jakarta adalah memberikan fasilitas-fasilitas yang dibutuhkan oleh wisatawan dan membuat tempat yang unik ala instagramable untuk berswafoto para wisatawan mancanegara maupun nusantara yang berkunjung ke Museum Sejarah Jakarta. Hal tersebut dilakukan untuk Museum Sejarah Jakarta semakin dikenal dan memberikan kesan supaya selalu ingin dikunjungi sebagai salah satu upaya meningkatkan pengunjung wisatawan mancanegara.

Berdasarkan hasil penelitian dan analisis yang telah dilakukan, maka peneliti mencoba memberikan saran dan masukan yang nantinya dapat dijadikan sebagai referensi bagi mahasiswa dalam strategi komunikasi serta menjadi acuan penelitian selanjutnya. 
Saran untuk organisasi:

1. Dengan adanya penelitian ini, diharapkan kepada pengelola Museum Sejarah Jakarta untuk memperbanyak fasilitas untuk berswafoto yang unik dan menarik.

2. Menambahkan penghijauan di kawasan Museum Sejarah Jakarta supaya menjaga kestabilan teriknya matahari.

3. Memperbanyak event atau seminar yang bertemakan edukasi di Museum Sejarah Jakarta.

Saran untuk akademis:

1. Dengan adanya penelitian ini, diharapkan dapat menambahkan wawasan untuk kajian strategi komunikasi pemasaran.

2. Diharapkan supaya instansi dapat menerapkan strategi komunikasi pemasaran yang lebih baik.

Saran untuk penelitian selanjutnya:

1. Diharapkan peneliti selanjutnya dengan topik yang sama dapat membahas dengan teori komunikasi pemasaran mengenai strategi komunikasi pemasaran.

Peneliti selanjutnya diharapkan untuk mengkaji lebih banyak sumber atau referensi yang terkait dengan strategi komunikasi pemasaran agar hasil penelitiannya lebih baik.

\section{DAFTAR PUSTAKA}

Arifin, Anwar. 2002. Ilmu Komunikasi: Sebuah Pengantar Ringkas. Rajagrafindo Persada. Jakarta.

Cangara, H. Hafied. 2013. Perencanaan dan Strategi Komunikasi Edisi Revisi. Jakarta: PT. Raja Grafindo Persada.

Cangara, Hafied. 2016. Pengantar Ilmu Komunikasi. Rajagrafindo Persada: Jakarta.

Dewi Fatikhatuz Zahro. 2015. Strategi Komunikasi Pemasaran Terpadu Desa Wisata dalam Meningkatkan Kunjungan Wisatawan. Jurnal Ilmu Komunikasi.
Gitosudarmo, Indriyo. 2017. Manajemen Pemasaran Edisi Kedua. BPFE: Yogyakarta. Gunawan, Iwan. 2013. Metode Penelitian Kualitatif: Teori dan Praktik. Jakarta: PT Bumi Aksara.

Hamzah Dzilqarnain. 2015. Strategi Komunikasi Pemasaran Universitas Muhammadiyah Magelang. Jurnal ilmu Komunikasi.

Ibnularoby. 2013. Persepsi Konsumen Terhadap Marketing Mix 7P Pada Perusahaan PO.SAN Bengkulu.

Imul Pratama. 2017. Strategi Komunikasi Pemasaran Dinas Kebudayaan Pariwisata Kota Kendari dalam Meningkatkan Jumlah Pengunjung Wisata Pantai Nambo Kendari. Jurnal Ilmu Komunikasi.

Liliweri, Alo. 2011. Komunikasi Serba Ada Serba Makna. Kencana Prenada Media Group: Jakarta.

Muthia Misdrinaya, 2017. Strategi Komunikasi Pemasaran Dinas Pariwisata Pemerintah Kota Makassar dalam Meningkatkan Kunjungan Wisatawan Mancanegara di Kota Makassar. Jurnal Ilmu Komunikasi.

Mulyana, Deddy. 2011. Ilmu Komunikasi: Sekarang dan Tantangan Masa Depan. Kencana Prenada Media Group. Jakarta.

Sunyoto, Danang. 2013. Manajemen Pemasaran (Pendekatan Konsep, Kasus, dan Psikologi Bisnis). CAPS (Center of Academic Publishing Service): Yogyakarta.

Sutryadi, Edi. 2018. Strategi Komunikasi Sebuah Analisis Teori dan Praktis di Era Global. Rosda: Bandung.

Yusniar Dwi Ratnasari. 2016. Strategi Komunikasi Pemasaran Dinas Pariwisata dan Kebudayaan Kabupaten Jepara dalam Meningkatkan Jumlah Pengunjung Pantai Tirta Samudra. Jurnal Ilmu Komunikasi.

Diskominfo. 2017. Museum Sejarah Jakarta. Diakses dari https://Jakarta.go.id/artikel/konten/2534/ museum-sejarah-Jakarta, pada tanggal 23 Desember 2018 pukul 13.06 . 